\title{
ENDOSCOPIC MANAGEMENT OF CORROSIVE ESOPHAGEAL STENOSIS BY TEMPORARY STENT PLACEMENT
}

\author{
Gelu-Cristian ROSIANU1,2®, Mihaela RUSU ${ }^{3}$, Vasile SANDRU ${ }^{3}$, Camelia DIACONU ${ }^{4}$, \\ Narcis COPCA ${ }^{5}$ \\ ${ }^{1}$ CESITO Center, „Sfanta Maria“ Clinical Hospital, Bucharest, Romania \\ 2 Department of Gastroenterology, „Sfanta Maria“ Clinical Hospital, Bucharest, Romania \\ ${ }^{3}$ Department of Gastroenterology, Clinical Emergency Hospital of Bucharest, Romania \\ ${ }^{4}$ "Carol Davila“ University of Medicine and Pharmacy, Department of Internal Medicine, Clinical \\ Emergency Hospital of Bucharest, Romania \\ ${ }^{5}$ Department of Surgery, „Sfanta Maria“ Clinical Hospital, Bucharest, Romania \\ Received 06 Mar 2018, Accepted 11 May 2018
}

\section{Abstract}

Introduction. Ingestion of corrosive substances often causes serious damage to the upper gastrointestinal mucosa, occasionally perforation and, in rare cases, death. Most of these events are accidental, especially in children and the elderly, and voluntary (for suicidal purposes) in adults. If the patient survives the acute episode, the long-term complications are mainly esophageal and/or gastric stenosis and esophageal cancer after $1-2$ decades of evolution. Endoscopic treatment of benign esophageal stenosis consists of dilation with Savary bougies and dilation balloon, esophageal stent assembly, with the purpose of restoring esophageal luminal patency. Superior digestive endoscopy plays an important role in the evaluation of benign esophageal stenosis in terms of the severity and the extent of stenosis.

Case presentation. We present the case of a 47 -yearold patient admitted to our clinic for dysphagia for solid and semi-solid foods. Endoscopy revealed an esophageal stricture due to the voluntary ingestion of caustic substance with suicidal purpose, 9 months

\section{Résumé}

Approche endoscopique de la sténose oesophagienne corrosive par la fixation d'une endoprothèse temporaire

Introduction. L'ingestion de substances caustiques provoque fréquemment de graves endommagements aux muqueuses du tractus gastro-intestinal supérieur, la perforation occasionnelle et rarement la mort du patient. La plupart de ces évènements sont accidentels surtout quand il s'agit d'enfants ou de personnes âgées et volontaires (à des fins suicidaires) dans les cas des adultes. Si le patient survit à l'épisode aigu, les complications à long terme sont principalement représentées par des sténoses œesophagiennes ou gastriques et après une ou deux décennies d'évolution par le cancer de l'œsophage. Le traitement endoscopique des sténoses bénignes de l'œsophage consiste en la dilatation par bougies Savary ou par ballon, le placement d'une endoprothèse osophagienne, afin de restaurer la perméabilité de l'œesophage. 
before presentation. After multiple sessions of endoscopic dilatation with Savary bougies, an esophageal stent was placed, that solved patient's dysphagia.

Conclusions. Post-caustic esophageal stenosis is a common cause of dysphagia in patients with ingestion of corrosive substances. Patients can benefit from endoscopic esophageal stent placement treatment.

Keywords: esophageal stenosis, dysphagia, Savary bougies, esophageal stent.

\section{INTRODUCTION}

The incidence of corrosive substances ingestion is high and the number of reported cases is small in poorly developed and developing countries ${ }^{1}$. Evolution is dependent on many factors such as the amount of ingested substance, the $\mathrm{pH}$ of the substance and the duration of exposure. Ingestion of alkaline substances produces liquefied necrosis with more limited prognosis than coagulated necrosis produced by the ingestion of acidic substances. The immediate complications following the ingestion of caustic substances are: upper digestive hemorrhage and upper digestive tract perforation. The late complications in patients who survive the initial episode are eso-gastric stenosis, gastro-colic fistula and esophageal neoplasm².

The main treatment for esophageal post-caustic stenosis is endoscopic dilation with Guillard-Savary bougies or balloon dilatation. Besides malignant indications, esophageal self expandable stents are used for refectory benign strictures, benign perforations, postoperative anastomotic leaks and benign fistulae $e^{3,4}$.

Two different strategies for stenting have been described. The metal and the plastic stents press against the esophageal wall, with food and secretions that pass through the stent itself5.

Of the most common post dilation complications we include refractory stenosis, odynophagia, hemorrhage, esophageal perforation and mediastinitis.

In the event of recurrence or ineffective endoscopic dilatation, it can be done a new session of endoscopic dilation with Savary bougies associated
Rapport du cas. L'endoscopie digestive supérieure joue un rôle important dans l'évaluation des sténoses bénignes de l'œesophage, en termes de gravité et d'extension des sténoses. Nous présentons le cas d'un patient de 47 ans qui est venu à notre clinique pour dysphagie résultant de l'ingestion d'aliments solides et semi-solides. L'endoscopie a montré une sténose oesophagienne causée par l'ingestion de substance corrosive à des fins suicidaires, 9 mois avant la présentation. Après plusieurs sessions de dilatation avec des bougies Savary il a été décidé de fixer une endoprothèse œsophagienne, pour solutionner la dysphagie du patient.

Conclusions. Les sténoses œsophagiennes caustiques sont une cause fréquente de dysphagie chez les patients qui ont ingéré des substances corrosives. Les patients peuvent bénéficier d'un traitement endoscopique.

Mots-clés: sténoses œesophagiennes, dysphagie, bougies Savary, stent œsophagien.

with corticosteroid injection, esophageal stent placement and endoscopic incision of stenosis ${ }^{6}$. The most common complications in patients treated with an esophageal stent are: stent migration, tissue in-and/ or overgrowth, food obstruction, hemorrhage, severe pain and ruptured esophagus.

\section{Case presentation}

We present the case of a 47-year-old patient, admitted to the Gastroenterology Clinic of the „Sf. Maria" Hospital, Bucharest, for solid and semi-solid foods dysphagia after voluntary ingestion of corrosive substance for suicidal purposes. The caustic ingestion episode occurred 9 months before presentation. From the medical history of the patient, we retain type II diabetes mellitus controlled with oral antidiabetic agents. Laboratory investigations revealed mild normochromic, normocytic anemia, hypoproteinemia and hypoalbuminemia.

An eso-gastro-duodenal barium passage was performed, which revealed tight esophageal stenosis in the lower third of the esophagus (Fig. 1).

Pulmonary radiography and abdominal ultrasound did not show any changes. It was decided to perform a superior digestive endoscopy, that highlighted tight esophageal stenosis, located in the lower third of the esophagus (Fig 2). Endoscopic dilatation with Savary bougies was performed, which relieved the dysphagia (Fig. 3).

After one year of endoscopic dilatation sessions with Savary bougies, they became ineffective. Due to the appearance of dysphagia for solid and semi-solide foods, 3 days after endoscopic dilation, it was decided 


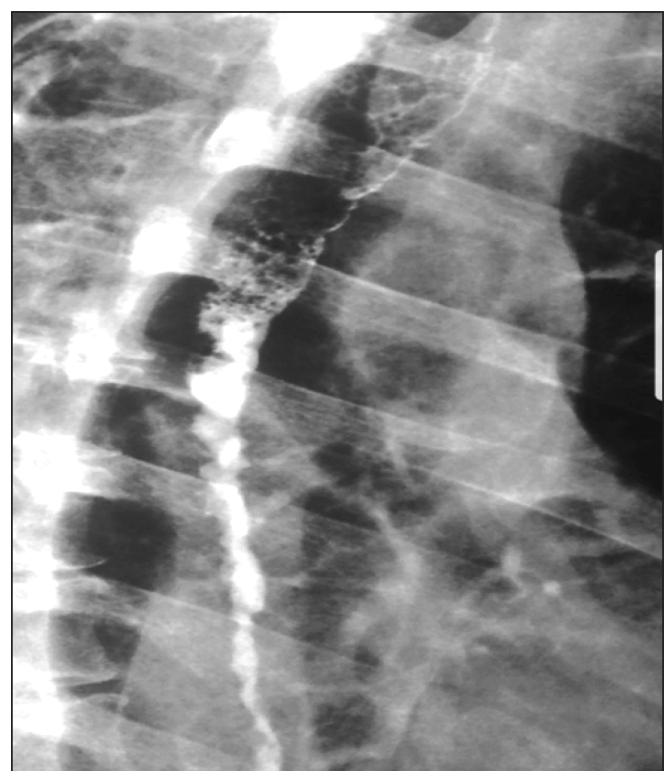

Figure 1. Radiography - esophageal post caustic stenosis.

to mount a fully covered esophageal stent of 100/20 mm (Fig 4).

The stent was maintained for 6 weeks, during which time the patient was fed normally. After this period the stent was removed and the esophageal stenosis did not recover.

\section{Discussion}

Benign esophageal stenoses are frequent causes of digestive diseases that reduce the quality of life $\mathrm{e}^{7-8}$. The most common causes of benign esophageal stenosis are: gastro-esophageal reflux, pharyngeal surgery, radiotherapy, submucosal esophageal resection, caustic ingestion, infectious factors - Candida, tuberculosis, syphilis, colon inflammation such as Crohn's disease with esophageal disorder ${ }^{9-10}$.

Ingestion of caustic substances may lead to lesions in the pharynx, larynx, esophagus, respiratory tract and stomach ${ }^{11-12}$.

The majority of benign esophageal stenosis can be successfully treated with bougies dilation ${ }^{13}$.

The dilation with Savary bougies and balloon dilation represent the main method of the treatment of benign esophageal stenosis ${ }^{14}$.

Stent insertion is not the first choice recommended procedure, due to its high rate of necrosis and ulceration, tissue hyperplasia, new stricture or fistula formation, and the tendency for the metal portion to embed within the esophageal wall ${ }^{15}$.

But the temporary stent insertion for refractory benign esophageal strictures may be useful, especially in those patients in whom other therapeutic options are unavailable or unsuccessful ${ }^{16}$.

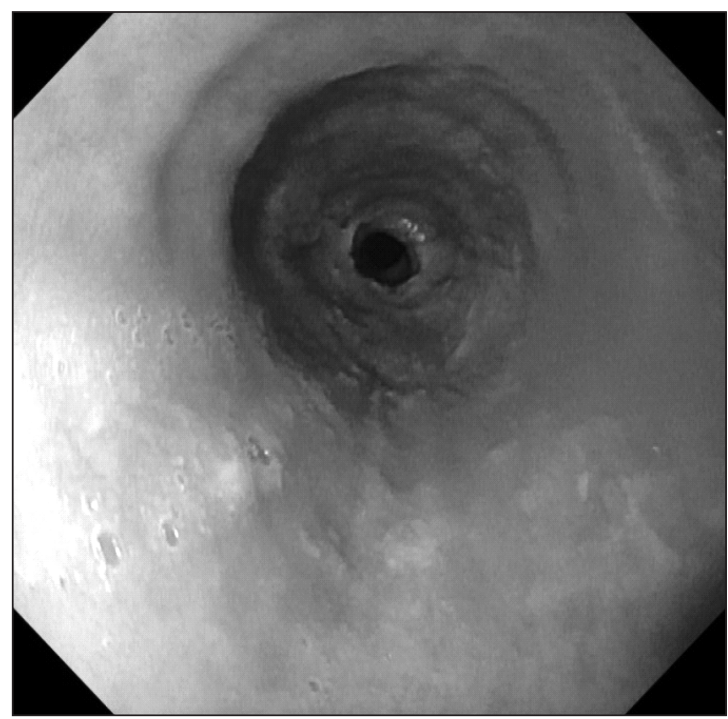

Figure 2. Endoscopic view esophageal post caustic stenosis.

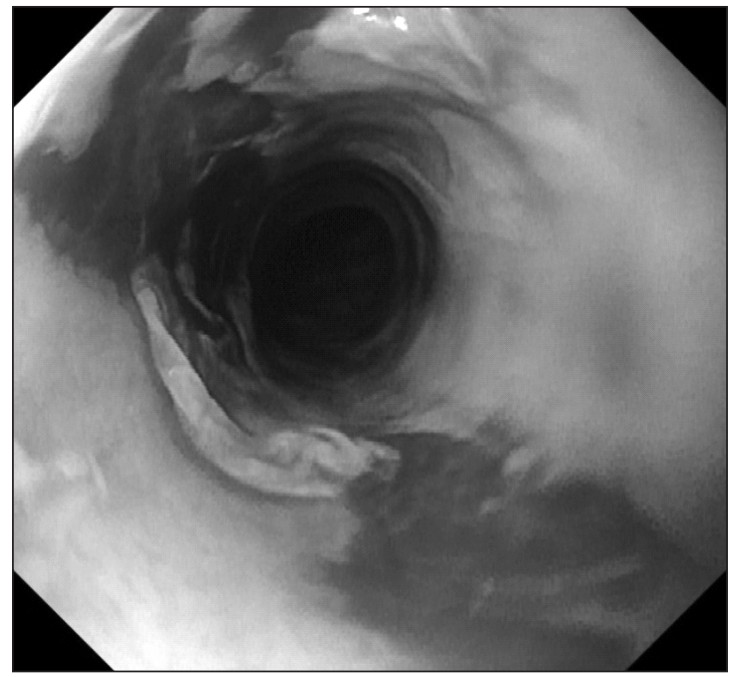

Figure 3. Endoscopic view - esophageal post caustic stenosis after endoscopic dilation.

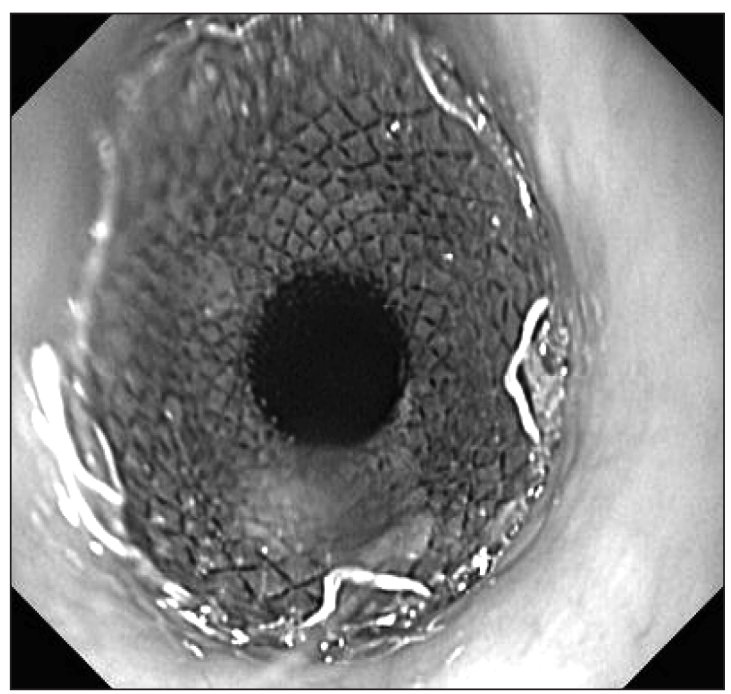

Figure 4. Esophageal stent. 


\section{Conclusions}

Dilation of benign post-caustic esophageal stenosis is a safe and effective therapeutic method in most cases, avoiding morbidity and mortality associated with operator risk. The purpose of esophageal dilatations is to obtain a permeable esophageal lumen with symptom relief. There are several techniques for endoscopic dilatation, but it is necessary to select a specific and individualized method for each patient so that the beneficial effect is maximal and complications are minimal. Endoscopic dilatation techniques should be performed by an experienced endoscopist in tertiary centers. Esophageal stenting remains the last therapeutic option when endoscopic dilation becomes ineffective.

\section{Compliance with Ethics Requirements:}

„The authors declare no conflict of interest regarding this article"

"The authors declare that all the procedures and experiments of this study respect the ethical standards in the Helsinki Declaration of 1975, as revised in 2008(5), as well as the national law. Informed consent was obtained from all the patients included in the study"

\section{References}

1. Contini S, Scarpignato C. Caustic injury of the upper gastrointestinal tract: A comprehensive review. World Journal of Gastroenterology, 2013;19(25):3918-30.

2. Vezakis AI, Pantiora EV, Kontis EA, et al. Clinical spectrum and management of caustic ingestion: a case series presenting three opposing outcomes. Am J Case Rep. 2016;17:340-6.

3. Cheng HT, Cheng CL, Lin CH, et al. Caustic ingestion in adults: the role of endoscopic classification in predicting outcome. BMC Gastroenterol. 2008;8:31.

4. van Halsema EE, van Hooft JE. Clinical outcomes of self expandable stent placement for benign esophageal diseases: a pooled analysis of the literature. World J Gastrointest Endosc. 2015; 7(2): 135-153.

5. van Boeckel PGA, Siersema PD. Refractory esophageal strictures: what to do when dilation fails. Curr Treat Options Ga stroenterol. 2015;13(1):47-58.

6. Dall' Oglio L, Caldaro T, Foschia F, et al. Endoscopic management of esophageal stenosis in children: New and tradional treatments. World J Gastrointest Endosc. 2016; 8(4):212-219.

7. Liu J, Shang L, Liu JY, Qin CY. Newly designed pieced stent in a rabbit model of benign esophageal stricture. World Journal of Gastroenterology. 2015; 21(28): 8629-8635.

8. Socea B, Smaranda CA, Nica AA, et al. Rare small bowel obstruction due to phytobezoar - case presentation. Archives of the Balkan Medical Union, 2017, 52(4):458-461.

9. Socea B, Nica A, Bratu O, et al. Incidental finding of a sigmoid intussusception associated with rectal prolapse a case report. Archives of the Balkan Medical Union, 2018, 53(1):143-146.

10. Kitajima T, Momose K, Lee S, et al. Benign esophageal stricture after thermal injury with esophagectomy and ileocolon interposition. World Journal of Gastroenterology. 2014; 20(27): 9205-9209.

11. Han Y, Cheng QS, Li XF, Wang XP. Surgical management of esophageal strictures after caustic burns: a 30 years of experience. World Journal of Gastroenterology. 2004; 10(19): 2846-2849.

12. Pahontu E, Paraschivescu C, Ilies DC, et al. Synthesis and characterization of novel $\mathrm{Cu}(\mathrm{II}), \mathrm{Pd}(\mathrm{II})$ and $\mathrm{Pt}(\mathrm{II})$ complexes with 8-ethyl-2-hydroxytricyclo 7.3.1.0(2,7)tridecan-13-one-thiosemicarbazone: antimicrobial and in vitro antiproliferative activity. Molecules, 2016; 21(5), piiE674.

13. Agarwalla A, Small AJ, Mendelson AH, Scott FI, Kochman ML. Risk of recurrent or refractory strictures and outcome of endoscopic dilation for radiation-induced esophageal strictures. Surg Endosc. 2015;29(7):1903-12.

14. Wen J, Lu Z, Liu Q. Prevention and treatment of esophageal stenosis after endoscopic submucosal dissection for early esophageal cancer. Gastroenterol Res Pract. 2014;2014:457101.

15. De Lusong MAA, Timbol ABG, Tuazon DJS. Management of esophageal caustic injury. World J Gastrointest Pharmacol Ther 2017; 8(2): 90-98.

16. Canena JMT, Manuel Liberato MJA, Rio-Tinto RAN, et al. A comparison of the temporary placement of 3 different self-expanding stents for the treatment of refractory benign esophageal strictures: a prospective multicentre study. BMC Gastroenterol. 2012;12:70. 